\title{
UPAYA WAKIL KEPALA MADRASAH DALAM PENGEMBANGAN BAKAT PESERTA DIDIK DI MTS AL MUHAJIRIN WAIHATU KECAMATAN KAIRATU KABUPATEN SERAM BAGIAN BARAT
}

\author{
Novita Harfianti Octavia ${ }^{1}$ \\ Institut Agama Islam Negeri (lain) Ambon \\ Vitaocta6@gmail.com
}

\begin{abstract}
Abstrak: Rumusan Masalah dalam penelitian ini, yakni: (a) Bagaimana upaya wakil kepala madrasah dalam pengembangan bakat peserta didik di MTs Al Muhajirin Waihatu? (b) Apa faktor pendukung dan penghambat dalam pengembangan bakat peserta didik di MTs Al Muhajirin Waihatu. Adapun yang menjadi tujuan penelitian ini adalah (a) untuk mengetahui upaya wakil kepala Madrasah dalam pengembangan bakat peserta didik di MTs AI Muhajirin Waihatu Kecamatan Kairatu Kabupaten Seram Bagian Barat, (b) untuk faktor pendukung dan penghambat dalam pengembangan bakat peserta didik di MTs Al Muhajirin Waihatu.

Penelitian ini menggunakan tipe penelitian yang digunakan adalah deskriptif kualitatif, dengan teknik pengumpulan data melalui observasi, wawancara, dan dokumentasi. Analisis data menggunakan reduksi data, penyajian data, dan menarik kesimpulan. Penelitian ini dilaksanakan selama satu bulan dari tanggal 04 Oktober 2018 sampai dengan 04 November 2018, berlokasi di MTs Al Muhajirin Waihatu Kecamatan Kairatu Kabupaten Seram Bagian Barat.

Hasil penelitian menunjukkan bahwa (1) Upaya wakil kepala madrasah bidang kesiswaan dalam mengembangkan bakat peserta didik di MTs Al Muhajirin Waihatu Kecamatan Kairatu Kabupaten Seram Bagian Barat, diantaranya: (a) Memberikan dukungan moral dan motivasi untuk peserta didik, (b) Melibatkan partisipasi orangtua, (c) Menyediakan sarana dan prasarana yang dibutuhkan, (d) Kegiatan itu dimasukkan ke kurikulum untuk dijadikan Ekstrakurikuler, (e) Mengikutsertakan peserta didik di perlombaan. (2) Beberapa faktor pendukung yaitu (a) Minat peserta didik dalam mengikuti ekstrakurikuler, (b) Para pendidik terlibat ikut serta dalam pelaksanaan pengembangan bakat di MTs Al Muhajirin Waihatu. Sedangkan faktor penghambat, yaitu; (a) Sarana dan prasarana yang kurang memadai, (b) Waktu yang kurang maksimal, (c) Pembimbing kegiatan ekstrakurikuler yang minim dan kurang kompenten dibidangnya, dan (d) Dana. Sehingga upaya wakil kepala madrasah dalam pengembangan bakat peserta didik dapat berjalan dengan baik.
\end{abstract}

Kata Kunci: Upaya Wakil Kepala Madrasah, Pengembangan Bakat.

\section{PENDAHULUAN}

Masa remaja merupakan sebuah periode dalam kehidupan manusia yang batasannya usia maupun peranannya seringkali terlalu jelas. Masa remaja adalah masa pencarian jati diri, salah satu yang dimiliki peserta didik pada usia remaja adalah potensi yang belum tergali. Potensi peserta didik adalah segala yang dimiliki peserta didik yang memungkinkannya untuk berkembang secara optimal. Potensi ini meliputi 
semua yang dimiliki peserta didik yang memungkinkan untuk tumbuh dan berkembang dalam aspek kognisi, emosi, dan sosial. ${ }^{2}$

Bakat adalah kemampuan yang merupakan sesuatu ada dalam diri seseorang yang dibawa sejak mereka lahir dan terkait dengan struktur otak. Secara genetis struktur otak memang telah terbentuk sejak lahir, tetapi berfungsinya otak itu sangat ditentukan oleh caranya lingkungan berinteraksi dengan manusia. Bakat dapat diartikan pula sebagai kemampuan bawaan yang merupakan potensi (potential ability) yang masih perlu dikembangkan dan dilatih. ${ }^{3}$

Mengacu pada pendapat Dr. Anders Ericsson dalam buku Cambridge Handbook of Expertise and Expert Performance, bahwa "orang-orang yang berbakat ialah orang yang selalu "diciptakan" atau "dilatih", dan bukan dilahirkan".

Peserta didik yang berbakat adalah peserta didik yang mampu mencapai prestasi tinggi, karena memiliki kemampuan-kemampuan yang unggul. Kemampuankemampuan tersebut meliputi kemampuan kecerdasan, kemampuan akademik khusus, kemampuan memimpin, kemampuan dalam salah satu bidang seni, kemampuan psikomotorik (bidang olahraga). ${ }^{4}$

Madrasah diartikan sebagai tempat belajar para pelajar atau tempat memberikan pelajaran. Oleh karena itu dalam proses belajar mengajar secara formal, madrasah tidak berbeda dengan sekolah, namun madrasah lebih dikenal dengan sebutan "sekolah agama". 5

MTs Al Muhajirin Waihatu dalam mengembangkan bakat mereka mempunyai permasalahan bagi peserta didik, diantaranya sebagian peserta didik kurang percaya diri dalam menampilkan bakat mereka, walaupun sebenarnya mereka punya. Ketidakpercayaan diri seringkali sangat merisaukan bagi peserta didik, ketidakpercayaan diri ini jika dibiarkan tentunya akan menghambat perkembangan jiwa

\footnotetext{
${ }^{2}$ Lusi Nuryanti, Psikologi Anak, (Jakarta: PT Index, 2008), hlm.56.

${ }^{3}$ Sunarto dan Hartono, Perkembangan Peserta Didik, (Jakarta: Rineka Cipta, 2002), hlm 119.

${ }^{4}$ Utami Munandar, Mengembangkan Bakat Dan Kreatifitas Anak Sekolah, (Jakarta: Gramedia, 1985),

${ }^{5}$ Ahmad Zayadi, Desain Pengembangan Madrasah, (Jakarta: Departemen Agama RI, 2005), hlm. 3.
} hlm.7-8 
peserta didik. Apalagi, peserta didik akan menghadapi kehidupan mendatang yang membutuhkan kekuatan jiwa serta keterampilan pengembangan dirinya termasuk dalam mengembangkan bakat yang ia miliki. Peserta didik juga terkadang malas untuk memulai mengembangkan bakatnya dikarenakan tidak ada kemauan dalam diri peserta didik biasanya dipengaruhi oleh lingkungan di sekitarnya dan sebagian peserta didik kurang dukungan dari orangtuanya. Disebabkan orang tua menyerahkan tugas dan tanggung jawabnya sepenuhnya kepada pendidik. Orang tua seringkali sibuk dengan pekerjaannya sehingga orang tua tidak memperhatikan bakat anak mereka sekaligus mengabaikannya". 6

Sehubungan dengan hal tersebut di atas MTs Al Muhajirin Waihatu adalah salah satu madrasah atau sekolah swasta yang mempunyai perhatian terhadap masalah pengembangan diri atau bakat. Jadi, salah satu tugas dan tanggung jawab wakil kepala madrasah bidang kesiswaan adalah bertanggung jawab di bidang ekstrakurikuler, dimana wakil kepala Madrasah bidang kesiswaan berupaya untuk pengembangan bakat peserta didik.

Pada tahun 2017 bertepatan dengan bulan suci Ramadhan, di MTs Al Muhajirin Waihatu mengadakan lomba Tahfidzhul Qur'an, murotal, adzan, kaligrafi dan tausiyah serta diadakan kegiatan seni Islam berupa qosidah pada hari besar Islam. Kegiatan ini termasuk memacu keberanian peserta didik, agar ketika mengikuti lomba di luar madrasah, peserta didik tidak lagi merasakan nervouse atau grogi. Dalam menjalankan sekaligus merencanakan kegiatan seperti ini agar berjalan lancar dibutuhkan perencanaan, yang bertanggung jawab atas pengembangan bakat peserta didik, yakni wakil kepala madrasah bidang kesiswaan. Berhubung sebagian peserta didik belum berani menampilkan bakat yang mereka miliki dengan kata lain yakni malu, selain itu juga peserta didik harus bisa tampil di luar madrasah bukan hanya di dalam madrasah saja, maka dibutuhkan upaya wakil kepala madrasah bidang kesiswaan untuk mengembangkan bakat peserta didik yang ada di MTs AI Muhajirin Waihatu Kabupaten Seram Bagian Barat.

\footnotetext{
${ }^{6}$ Hassan Basri, Kepala Sekolah MTs Al Muhajirin Waihatu, Wawancara, 17 April 2018.
} 
Berdasarkan latar belakang di atas, penulis merasa tertarik untuk melakukan penelitian tentang upaya wakil kepala madrasah bidang kesiswaan dalam pengembangan bakat peserta didik di MTs AI Muhajirin Waihatu Kecamatan Kairatu.

\section{METODE}

Untuk dapat mengetahui upaya wakil kepala Madrasah dalam pengembangan bakat peserta didik di MTs Al-Muhajirin aihatu Kecamatan Kairatu kabupaten Seram bagian Barat akan digunakan jenis penelitian kualitatif. Penelitian deskriptif itu berusaha untuk memperoleh gambaran secara lengkap dan detail tentang kejadian dan fenomena tertentu pada suatu objek dan subjek yang memiliki kekhasan. Dengan demikian pelaksanaan penelitian adalah menggali informasi sebanyak-banyaknya dan sedalam-dalamnya kemudian mendiskripsikannya dalam bentuk naratif sehingga memberikan gambaran secara utuh tentang fenomena yang terjadi. ${ }^{7}$ Penulis akan menggunakan tiga metode dalam pengumpulan data dan informasi yaitu: observasi, wawancara, dan dokumentasi, serta teknik analisis data terdiri dari reduksi data, penyajian data, menarik kesimpulan.

\section{TINJAUAN PUSTAKA}

\section{A. Fungsi dan Peranan Kepala Madrasah dalam Pengembangan Bakat}

Wakil kepala sekolah untuk di madrasah lebih dikenal dengan sebutan wakil kepala madrasah atau wakamad. Seorang wakamad adalah orang yang membantu kepala madrasah. Pembantu kepala madrasah di sini adalah administrator profesional kedua dalam wewenang sesudah kepala madrasah. ${ }^{8}$

a) Program Kegiatan Wakil Kepala Madrasah Bidang Kesiswaan

1. Penerimaan dan penunjukkan peserta didik kepada kelas dan program studi.

\footnotetext{
${ }^{7}$ Wina Sanjaya, Penulisan Pendidikan Jenis, Metode Dan Prosedur, (Jakarta : Kencana, 2015), hlm. 47-48.

${ }^{8}$ Oteng Sutisna. Administrasi Pendidikan Dasar Teoritis Untuk Praktek Profesional. (Bandung: Angkasa, 1987), hlm. 183.
} 
2. Evaluasi dan pelaporan kemajuan peserta didik.

3. Mengendalikan disiplin peserta didik.

4. Program bimbingan.

b) Wewenang Wakil Kepala Madrasah Bidang Kesiswaan

1. Mewakili kepala madrasah apabila tidak ada ditempat.

2. Menyusun daftar pembagian tugas peserta didik untuk memelihara kebersihan madrasah.

3. Memilih peserta didik untuk penerimaan beasiswa, paskibraka serta peserta didik yang teladan.

4. Terbinanya kegiatan lomba-lomba bidang non akademis.

5. Mengatur mutasi peserta didik.

6. Menyusun program kegiatan eksrakurikuler.

7. Menyiapkan peserta didik untuk kegiatan ekstrakurikuler. ${ }^{9}$

c) Tanggung Jawab Wakil Kepala Madrasah Bidang Kesiswaan

1. Bertanggung jawab atas keberhasilan pembinaan kesiswaan.

2. Bertanggung jawab atas peningkatan prestasi peserta didik, khususnya di bidang ekstrakurikuler.

3. Bertanggung jawab atas tugas intern kepala madrasah, apabila kepala madrasah tidak ada di tempat sesuai dengan batas kewenangan yang diberikan oleh kepala madrasah.

\section{B. Pengembangan Bakat}

\footnotetext{
${ }^{9}$ Ibid., hlm. 77.
} 


\section{Pengertian Bakat}

Bakat Menurut Freeman, sebagaimana yang dikutip oleh Abdul Rahman dalam bukunya yang berjudul "Psikologi Dalam Perspektif Islam":

"Bakat adalah sifat-sifat yang memberi petunjuk akan adanya kemampuan yang akan dimiliki seseorang, yang dengan melalui latihan-latihan dapat direalisasi menjadi kemampuan-kemampuan yang nyata, terutama dalam bidang-bidang khusus, misalnya dalam bidang bahasa, seni musik, dan bidang teknik."10

Kecerdasan aksara adalah potensi. Menulis buku adalah bakat. Menulis skenario film adalah bakat. Kecerdasan sosial adalah potensi, menjual barang adalah bakat. Bakat adalah hasil belajar berkelanjutan pada suatu bidang tertentu. Tanpa adanya belajar dan berlatih, maka suatu bakat yang dimiliki tidak akan berkembang, karena bakat itu adalah bawaan dari lahir.

Menurut Bukik Setiawan "Bakat adalah hasil belajar seseorang dan pada dasarnya seseorang bisa mempunyai lebih dari satu bakat, tergantung dengan kesesuaian potensi diri dan kesempatan di masyarakat. Bakat adalah tindakan nyata atau karya yang dihasilkan seseorang yang dihargai masyarakat. Tanpa tindakan atau karya, maka hanya menjadi potensi." ${ }^{11}$

Biasanya seseorang disebut mempunyai bakat apabila orang tersebut menghasilkan karya, keterampilan, kemampuan, kapasitas dan sebagainya. Bakat (aptitude) diartikan sebagai kemampuan bawaan yang merupakan potensi (potensial ability) yang masih perlu dikembangkan atau dilatih. Kemampuan (ability) adalah daya untuk melakukan suatu tindakan sebagai hasil dari pembawaan dan latihan.

\section{HASIL}

${ }^{10}$ Abdul Rahman Shaleh dan Muhbib, Psikologi Dalam Perspektif Islam, (Jakarta: Predana Media, 2005), hlm. 253-254.

${ }^{11}$ Bukik Setiawan, Andri Firdaus, Bakat Bukan Takdir, (Jakarta: Lentera Hati Group,2016), hlm. 21-22 


\section{Upaya Wakil Kepala Bidang Kesiswaan Madrasah dalam Pengembangan Bakat Peserta Didik di MTs AI Muhajirin Waihatu}

MTs Al Muhajirin Waihatu memiliki dua kegiatan ektrakurikuler dalam bidang keagamaan, yaitu: Qosidah dan Tahfidzhul Qur'an. Ekstrakurikuler Qosidah di MTs Al Muhajirin Waihatu dilaksanakan sejak tahun 2014 atau 4 tahun yang lalu. Tujuan diadakan ekstrakurikuler Qosidah adalah untuk mewadahi peserta didik yang berbakat di bidang seni musik islami dan juga mempersiapkan lomba serta mempersiapkan diri jika ada kegiatan di masyarakat seperti perayaan hari besar Islam Maulid Nabi Muhammad SAW. Ekstrakurikuler Tahfidzhul Qur'an di MTs Al Muhajirin Waihatu dilaksanakan sejak tahun 2016 atau 2 tahun yang lalu. Tujuan diadakan ekstrakurikuler Tahfidzhul Qur'an adalah untuk mewadahi peserta didik yang berbakat di bidang menghafal al-Qur'an.

Berdasarkan hasil penulisan yang dilakukan oleh penulis terkait dengan Upaya Wakil Kepala Madrasah bidang Kesiswaan dalam Pengembangan Bakat peserta didik dalam bidang Qosidah dan Tahfidzhul Qur'an, meliputi:

a) Memberikan Dukungan Moral dan Motivasi untuk Peserta Didik.

Pada kegiatan ekstrakurikuler Qosidah, hal ini bertujuan agar peserta didik selalu memiliki semangat dalam mengikuti kegiatan Qosidah. Motivasi ini diberikan setiap mengawali kegiatan latihan, pada saat akan lomba dan selesai lomba. Berbeda dengan ekstrakurikuler Tahfidzhul Qur'an, Tahfidzhul Qur'an bertujuan agar peserta didik selalu memiliki semangat dalam mengikuti kegiatan Tahfidzhul Qur'an, dengan menyebutkan ayat-ayat al-Qur'an dan hadits Nabi tentang keutamaan menghafal al-Qur'an, bahwa dengan menghafal al-Qur'an seseorang akan memiliki derajat yang tinggi di sisi Allah SWT.

b) Melibatkan partisipasi Orangtua

Wakil kepala madrasah berupaya melibatkan partisipasi orang tua peserta didik. Karena yang lebih utama pendidikan di dalam rumah, sebagai orang tua harus bisa 
memberikan motivasi dan mengajarkan atau mengulangi kembali di rumah materi yang telah didapat.

c) Menyediakan sarana dan prasarana yang dibutuhkan.

Sarana dan prasarana sangat menujang bagi peserta didik dalam mengembangkan bakat mereka, ada beberapa sarana dan prasarana yang kurang lengkap, diantaranya pengeras suara, rebana, ruang latihan. Sementara untuk Tahfidzhul Qur'an, pengalokasian dana untuk pengadaan media belajar Tahfidzhul Qur'an agar kegiatan Tahfidzhul Qur'an lebih menarik dan ke depannya diharapkan adanya pengalokasian dana untuk pembangunan musholah sebagai sentra kegiatan ibadah (Sholat dan Tahfidzhul Qur'an), Penyediaan perangkat multimedia (Video Tahfidzhul Qur'an), alat-alat peraga Tahfidzhul Qur'an, al-Qur'an.

d) Kegiatan itu dimasukkan de Kurikulum, untuk dijadikan Ekstrakurikuler

Kegiatan Qosidah dan Tahfidzhul Qur'an yang dijadikan ekstrakurikuler, mempermudah penjaringan peserta didik untuk terlibat dalam kedua kegiatan tersebut. Selain itu, akan teralokasikan waktu khusus untuk kegiatan latihan ekstrakurikuler Qosidah dan Tahfidzhul Qur'an. Sehingga peserta didik lebih maksimal dalam latihan dan terbangunnya rasa tanggung jawab peserta didik.

e) Mengikutsertakan Peserta Didik di Perlombaan

Pihak madrasah terlibat aktif dalam mendaftarkan peseta didik pada perlombaan yang diadakan baik di tingkat Desa, Kecamatan maupun Kabupaten, ketika peserta didik terlibat dalam perlombaan, maka ada alokasi waktu tambahan latihan dan dispensasi dari pihak madrasah bagi peseta didik untuk tidak mengikuti kegiatan belajar mengajar secara normal.

2. Faktor-Faktor Pendukung dan Penghambat dalam Pengembangan Bakat Peserta Didik Di MTs AI Muhajirin Waihatu

a) Faktor Pendukung

1. Minat Peserta Didik dalam Mengikuti Ekstrakurikuler 
Hal ini terbukti dengan banyaknya peserta didik yang terlibat dalam kegiatan ekstrakurikuler Qosidah (2 tim) yang berjumlah 20 peserta didik dan antusias peserta didik dalam mengikuti latihan yang diadakan. Begitu juga dengan Tahfidzhul Qur'an yang terlibat di kegiatan Tahfidzhul Qur'an berjumlah 25 yag dibagi menjadi dua kelompok berdasarkan jenis kelamin. Antusias peserta didik dalam mengikuti kegiatan ekstrakurikuler Tahfidzhul al-Qur'an.

2. Para Pendidik Ikut Serta dalam Pelaksanaan Pengembangan Bakat

Para pendidik ikut membantu untuk menggerakkan peserta didik yang mengikuti kegiatan tersebut.

\section{b) Faktor Penghambat}

1. Sarana dan prasarana yang kurang memadai

Sarana dan prasarana yang kuarang memadai diantaranya: pengeras suara, rebana, proyektor dan soundsystem, serta al-Qur'an.

2. Waktu yang Kurang Maksimal

Interval waktu yang disedikan hanya satu hari dalam sepekan dari jam 14.30 WIT sampai dengan 16.30 WIT. Padahal, peserta didik pulang pukul 13.30 WIT. jarak dari waktu pulang sekolah untuk kembali lagi ke sekolah itu hanya satu jam. Mereka nyaris tidak punya waktu yang cukup untuk istirahat.

3. Pembimbing Kegiatan Ekstrakurikuler yang Minim serta Berkompeten

Selama ini yang melatih peserta didik hanya Tiga orang pendidik untuk melatih dua tim. Pendidik tersebut pun harus melatih ketiga aspek di atas (penggunaan alat musik, tarik suara,dan koreografi).

\section{Dana}

Dana memang bukan segala-galanya, namun tanpa dana yang memadai bisa dipastikan banyak hal akan gagal, termasuk kegiatan ekstrakurikuler Qosidah dan Tahfidzhul Qur'an. Tenaga pengajar yang seadanya, sarana yang kurang, prasarana yang tidak memadai. Semuanya bisa teratasi dengan pengalokasian dana yang cukup.

\section{PEMBAHASAN}




\section{Upaya Wakil Kepala Madrasah Bidang Kesiswaan dalam Pengembangan Bakat Peserta Didik di MTs AI Muhajirin Waihatu}

Bakat adalah hasil belajar seseorang dan pada dasarnya seseorang bisa mempunyai lebih dari satu bakat, tergantung dengan kesesuaian potensi diri dan kesempatan di masyarakat, tindakan nyata atau karya yang dihasilkan seseorang yang dihargai masyarakat. Tanpa tindakan atau karya, maka hanya menjadi potensi. ${ }^{12}$

Peserta didik berbakat adalah mereka yang oleh orang-orang profesional diidentifikasi sebagai anak yang mampu mencapai prestasi yang tinggi karena mempunyai kemampuan-kemampuan yang unggul. ${ }^{13}$ Bakat anak biasanya disalurkan melalui kegiatan-kegiatan seperti kegiatan ekstrakurikuler keagamaan.

Ekstrakurikuler keagamaan di MTs Al Muhajirin Waihatu ada dua yaitu ekstrakurikuler Qosidah dan Tahfidzhul Qur'an. Jika dilihat dari jenis-jenis bakat, kedua ekstrakurikuler ini termasuk bakat khusus. Bakat khusus merupakan kemampuan yang berupa potensi khusus, artinya tidak semua orang memiliki. ${ }^{14}$

Dari hasil wawancara dengan kepala madrasah, wakil kepala madrasah bidang kesiswaan, pembimbing Qosidah dan Tahfidzhul Qur'an, dan beberapa peserta didik di MTs Al Muhajirin Waihatu. Penulis dapat mengetahui "Upaya Wakil Kepala Madrasah Bidang Kesiswaan dalam Pengembangan Bakat Peserta Didik", yaitu (1) Memberikan Dukungan moral dan motivasi untuk peseta didik, (2) Melibatkan partisipasi orangtua,

${ }^{12}$ Bukik Setiawan, Andri Firdaus, Bakat Bukan Takdir, (Jakarta: Lentera Hati Group, 2016), hlm. 21-22.

${ }^{13}$ Munandar, Utami. Kreativitas dan Keberbakatan (Jakarta: PT Gramedia Pustaka Utama, 2002), hlm. 30.

${ }^{14}$ Firna Yanti Runbouw, "Pengaruh Komite Terhadap Peningkatan Bakat Siswa Pada Bidang Studi PAI Kelas VIII Studi Di SMP Negeri 6 Kecamatan Pulau Gorom Kabupaten Seram Bagian Timur", Skripsi Sarjana Pendidikan, (Ambon: PAI Fakultas Ilmu Tarbiyah dan Keguruan IAIN Ambon, 2014), hlm.31-32. 
(3) Menyediakan sarana dan prasarana yang dibutuhkan, (4) Kegiatan Qosidah dan Tahfidzhul Qur'an dimasukkan ke kurikulum untuk dijadikan ekstrakurikuler, (5) Mengikutsertakan peserta didik di perlombaan.

Wakil kepala madrasah berupaya memberikan dukungan moral dan motivasi kepada peserta didik, setiap kali pertemuan pasti diadakan evaluasi dan Alhamdulillah dari hari ke hari peserta didik lebih terlihat perubahan yang awalnya bermalas-malasan sekarang menjadi bersemangat tidak mengantuk dalam ruangan, peserta didik antusias memerhatikan saat pengajar memberikan materi, dan semakin disiplin waktu.

Dalam mengelola kesiswaan, wakil kepala madrasah bidang kesiswaan membantu kepala madrasah dalam beberapa hal, yaitu:

1. Melakspeserta didikan penerimaan peserta didik baru.

a. Merumuskan sistem penerimaan peserta didik baru sesuai dengan acuan yang berlaku.

b. Membentuk tim penerimaan peserta didik baru sesuai kebutuhan.

c. Mengkoordinasi pelaksanaan penerimaan peserta didik baru.

2. Mengembangkan potensi peserta didik sesuai minat, bakat, kreativitas dan kemampuan.

a. Mengembangkan sistem pengembangan potensi peserta didik sesuai dengan minat, bakat, dan kemampuan peserta didik.

b. Mengkoordinasi pelaksanaan pengembangan minat, bakat, kreativitas dan kemampuan peserta didik.

3. Menerapkan sistem bimbingan dan konseling 
a. Mengembangkan sistem bimbingan dan konseling sesuai program pengembangan peserta didik.

b. Mengkoordinasi sistem bimbingan dan konseling.

c. Mengevaluasi pelaksanaan bimbingan dan konseling.

d. Mengkoordinasikan penempatan peserta didik dan studi lanjutan.

e. Mengkoordinasi pengawasan peserta didik.

4. Menerapkan sistem pelaporan perkembangan peserta didik

a. Mengidentifikasi sistem pelaporan perkembangan peserta didik sesuai aturan yang berlaku.

b. Mengumpulkan dan menganalisis data perkembangan peserta didik kepada pihakpihak yang terkait. ${ }^{15}$

Sehubungan dengan penelitian ini tentang upaya wakil kepala madrasah dalam pengembangan bakat peserta didik di MTs Al Muhajirin Waihatu berdasaran mengelola kesiswaan, wakil kepala madrasah bidang kesiswaan membantu kepala madrasah dalam beberapa hal terdapat pada poin ke dua yaitu mengembangkan potensi peserta didik sesuai minat, bakat, kreativitas dan kemampuan serta poin ke empat menerapkan sistem pelaporan perkembangan peserta didik.

Wakil kepala madrasah bidang kesiswaan merupakan administrator yang diberi tanggung jawab dalam bidang kegiatan peserta didik di madrasah atau dalam hal pengembangan dan pembinaan. Tindakan pembinaan dan pengembangan tersebut dapat berupa bimbingan, pemberian informasi, yang pada hakekatnya adalah

${ }^{15}$ Departemen Pendidikan dan Kebudayaan. Pola Pembinaan dan Pengembangan Kesiswaan, (Jakarta:Direktorat Jenderal Pendidikan Dasar dan Menengah, 1980), hlm. 78. 
menciptakan suatu iklim yang sehat, agar kreatifitas peserta didik berkembang. Wakil kepala madrasah bidang kesiswaan berfungsi untuk mengatur berbagai kegiatan dalam bidang kesiswaan, agar kegiatan pembelajaran di madrasah dapat berjalan lancar, tertib dan teratur, serta pencapai tujuan pendidikan di madrasah.

\section{Faktor-faktor Pendukung dan Penghambat dalam Pengembangan Bakat Peserta Didik di MTs Al Muhajirin Waihatu}

Adapun faktor pendukung dalam pengembangan bakat peserta didik dapat ditinjau dari (1) Minat peserta didik dalam mengikuti ekstrakurikuler qosidah dan Ekstrakurikuler Tahfidzhul Qur'an, (2) Para pendidik juga terlibat ikut serta dalam pelaksanaan pengembangan bakat di MTs Al Muhajirin Waihatu. Sedangkan faktor penghambat dihadapi oleh wakil kepala madrasah dalam pengembangan bakat peserta didik di MTs Al Muhajirin Waihatu Kecamatan Kairatu Kabupaten Seram Bagian Barat adalah (1) Sarana dan prasarana yang kurang memadai, (2) Waktu yang kurang maksimal, (3) Pembimbing atau Pelatih kegiatan ekstrakurikuler yang minim serta kurang berkompeten di bidangnya dan (4) Dana.

\section{KESIMPULAN}

Penelitian yang dilakukan penulis dengan judul "Upaya wakil kepala madrasah dalam pengembangan bakat peserta didik di MTs Al Muhajirin Waihatu Kecamatan Kairatu Kabupaten Seram Bagian Barat". Berdasarkan data yang diperoleh dari observasi, wawancara serta dokumentasi dapat disimpulkan sebagai berikut: 
1. Upaya Wakil Kepala madrasah bidang kesiswaan dalam pengembangan bakat peserta didik, yaitu: (a) Memberikan dukungan moral dan motivasi peserta didik, (b) Melibatkan partisipasi orangtua, (c) Menyediakan sarana dan prasarana yang dibutuhkan (d) Kegiatan ekstrakurikuler Qosidah dan Tahfidzhul Qur'an dimasukkan ke kurikulum untuk dijadikan ekstrakurikuler, dan (e) Mengikutsertakan peserta didik di perlombaan. Sehingga Wakil kepala madrasah bidang kesiswaan berfungsi untuk mengatur berbagai kegiatan dalam bidang kesiswaan dapat berjalan dengan baik.

2. Faktor Pendukung upaya wakil kepala madrasah dalam pengembangan bakat peserta didik di MTs Al Muhajirin Waihatu kecamatan Kairatu Kabupaten Seram Bagian Barat adalah (a) Minat peserta didik dalam mengikuti ekstrakurikuler Qosidah dan ekstrakurikuler Tahfidzhul Qur'an, (b) Para Pendidik juga terlibat Ikut serta dalam pengembangan bakat. Sedangkan Faktor penghambat terletak pada (a) sarana dan Prasarana yang kurang memadai (b) waktu yang kurang maksimal, (c) pembimbing atau pelatih yang minim serta kurang berkompetensi di bidangnya, dan (d) Dana.

\section{UCAPAN TERIMA KASIH}

Penghargaan dan terima kasih yang setulus-tulusnya kepada Ayahanda Junat dan Ibunda Sumiati yang kusayangi yang telah mencurahkan segenap cinta dan kasih sayang serta perhatian moril maupun materil. Semoga Allah SWT selalu melimpahkan Rahmat, Kesehatan, Karunia dan keberkahan di dunia dan di akhirat atas budi baik yang telah diberikan kepada penulis, serta para dosen dan sahabat yang selalu menyuport penulis dari awal penyusunan skripsi hingga selesai. 


\section{DAFTAR PUSTAKA}

1. Arikunto, (2002) Suharsimi. Prosedur Penelitian Pendekatan Praktek, Edisi V.Jakarta: Rineka Cipta, . $\leftarrow$ BUKU

2. Arum Wahyuni, Susi (2016) "Peran Guru Bimbingan dan Konseling dalam Mengembangkan Minat dan Bakat Program pilihan Studi Keterampilan Peserta didik MAN 1 Magelang". Skripsi Sarjana Pendidikan, Yogyakarta: Sunan Kalijaga, $\leftarrow$ SKRIPSI

3. Departemen Pendidikan dan Kebudayaan, (1980). Pola Pembinaan dan Pengembangan Kesiswaan.Jakarta:Direktur Jenderal Pendidikan Dasar dan Menengah, $\leftarrow$ BUKU

4. Fathurrohman, Aris (2014) "Upaya Wakil Kepala Sekolah Bidang Keislaman Terhadap Kegiatan Pendidikan Agama Islam Di SMP Muhammadiyyah 1 Surakarta". Skripsi Sarjana Pendidikan Surakarta, Fakultas Agama Islam Tarbiyyah, $\leftarrow$ SKRIPSI

5. Fungsi dan Tugas Wakil Kepala, (http://www.bacaanpopuler.com/2016/10/fungsidan-tugas-tugas-wakil-kepala.html?m=1 10 oktober 2016, diakses tanggal 31 Desember 2017). $\leftarrow$ INTERNET

6. Gunarsa, Singgih D. (1982). Dasar Dan Teori Perkembangan Anak, Jakarta:BPK Gunung Mulia, $\leftarrow$ BUKU

7. Imam Machaly, Ara Hidayat. (2010) Pengelolaan Pendidikan, Bandung: Pustaka Educa, $\leftarrow$ BUKU

8. Junaidi, Iskandar.(2011). Mencetak Anak Unggul. Yogyakarta: C.V Andi Offset, $\leftarrow$ BUKU

9. Munandar,Utami. (1985) Mengembangkan Bakat Dan Kreatifitas Anak Sekolah. Jakarta: Gramedia, $\leftarrow$ BUKU

10. Nuryanti, Lusi. (2008) Psikologi Anak, (Jakarta: PT Index, $\leftarrow$ BUKU

11. Putra, Rizema, Stiatava.(2003) Panduan Pendidikan Berbasis Bakat Siswa. Jogjakarta: Diva Press,. $\leftarrow$ BUKU 
12. Riodani, Nohan. (2013) "Peran Guru Pendidikan Agama Islam Dalam Meningkatkan Perilaku Islami Siswa Di Smknegeri 1 Boyolangu Tulungagung", $\leftarrow$ SKRIPSI

13. Rumatiga, Asrul (2017) "Peran Wakil Kepala Sekolah (wakasek) Kesiswaan dalam mengadapo kenakalan peserta didik kelas VIII Studi di SMP Negeri 4 Salahutu Kabupaten Maluku Tengah". Skripsi Sarjana Pendidikan, Ambon: FITK Pendidikan Agama Islam,. $\leftarrow$ SKRIPSI

14. Runbouw, Yanti, Firna (2014) "Pengaruh Komite Terhadap Peningkatan Bakat Siswa Pada Bidang Studi PAI Kelas VIII Studi Di SMP Negeri 6 Kecamatan Pulau Gorom Kabupaten Seram Bagian Timur", Skripsi Sarjana Pendidikan, Ambon, Fakultas IImu Tarbiyah dan Keguruan Pendidikan Agama Islam. $\leftarrow$ SKRIPSI

15. Sangadji, Burdah. (2017) Peran Direktur Ma'had Dalam Mengembangkan NilaiNilai Pendidikan Islam Di Ma'had Al-Jami'ah lain Ambon. Skripsi Sarjana Pendidikan, (Ambon: Fakultas Tarbiyah Pendidikan Agama Islam,). $\leftarrow$ SKRIPSI

16. Sanjaya,Wina. (2015) Penelitian Pendidikan Jenis, Metode Dan Prosedur, Jakarta : Kencana,. $\leftarrow$ BUKU

17. Semiawan, Conny. (1997) Perspektif Pendidikan Anak Berbakat. Jogjakarta: Grasindo, $\leftarrow$ BUKU

18. Setiawan, Bukik \& Firdaus, Andri. (2016). Bakat Bukan Takdir, Jakarta: Lentera Hati Group,. $\leftarrow$ BUKU

19. Shaleh, Abdul Rahman dan Muhbib. (2005) Psikologi Dalam Perspektif Islam, Jakarta: Predana Medis. $\leftarrow$ BUKU

20. Singarimbun, Masri dan Effendi, Sofyan. (1989). Metode Penelitian Survai Jakarta: LP3ES. $\leftarrow$ BUKU

21. Soetopo, Hendyat \& Sumanto, Wasty. (1982). Pengantar Operasional Administrasi Pendidikan, Surabaya: Usaha Nasional. $\leftarrow$ BUKU

22. Sunarto dan Hartono. (2002) Perkembangan Peserta Didik. Jakarta: Rineka Cipta. $\leftarrow$ BUKU

23. Sutisna, Oteng. (1987). Administrasi Pendidikan Dasar Teoritis Untuk Praktek Profesional. Bandung: Angkasa. $\leftarrow$ BUKU 
24. Ta'rifin, Ainurrafiq A.(2005) Manajemen Madrasah Berbasis Pesantren, Yogyakarta: Listfariska Putra. $\leftarrow$ BUKU

25. Udin, (2011) "Fungsi Bimbingan Konseling Sekolah dalam Mengembangkan Bakat Siswa Studi di SMUN 1 Pagaden, Subang, Jawa Barat".Skripsi Sarjana Pendidikan, Yogyakarta: Fakultas Dakwah. $\leftarrow$ SKRIPSI

26. Zayadi, Ahmad. (2005) Desain Pengembangan Madrasah. Jakarta: Depag RI. $\leftarrow$ BUKU 